These problems have interested Vandebroek for many years, and he has developed his own ideas on several matters. For example, he believes that Van Beneden's theory of the homology of the coelomic sacs of vertebrates with the mesenteric recesses of cerianthid coelenterates has been unfairly dismissed by modern workers. Vandebroek discusses this problem at length, with details of his own work, and concludes that Van Beneden was correct. Studies on gastrulation and the closure of the blastopore have further convineed him that the chordates are not related to the echinoderms and enteropneusts, but are more closely allied to the protostomos. This viow in turn leads him to make comparisons betwoon the circulatory and excretory systems of chordates and annelids based on the belief that they are basically homologous. Such views are highly controversial, and it is unfortunate that they have first been published in a book of this kind, rather than being first exposed to the winds of eriticism and discussion by publication in a scientific journal. Vandebroek also believes that the monotremes are descended from the Permian dicynodont reptiles. Finally, he has elaborated a new theory on the homologies and evolution of the molar cusps in mammals, together with a complete new terminology for these cusps. This theory is thoroughly presented in his book, with the aid of a large number of excellent figures and photographs of the molar teeth of mammals. Published in 1961, his theory has not so far received any measure of acceptance from other workers in this field.

It is clear that Vandebroek's book is not suitable for the newcomer to this field of enquiry, who requires an explanation of the genorally accopted view on these matters which he can then elaborate by reference to other textbooks. It will instead be of interest to the proponents of tho "generally accepted vicw" who may wish to test it against tho theories proposed by Vandebrock and, in the process, criticizo his thoories in their turn.

The book is extromely woll produced, with many new and excollont figures and photographs. In contrast, tho reader who wishes to consult tho original papers which have influenced Vandebroek's thinking will unfortunately find, by way of a bibliography, merely a list of forty-six general textbooks.

BARRY Cox

\section{DEVELOPMENT OF MALIGNANCY}

\section{The Cancer Problem}

A Critical Analysis and Modern Synthesis. By Armin C. Braun. Pp. ix +209 . (Columbia University Press: New York and London, February 1970.) \$8.50; $76 s$.

IN cancer research, it scems that a disproportionate amount of attention has been given to the growth of malignant cells per se, compared with normal cells, and tissues. This very good book forces one to put malignancy in a much more meaningful perspective within the framework of ecll and developmental biology. The central thesis is that the tumour problem is what controls the growth of normal cells and where this control breaks down in neo. plasia. Metastasis and invasiveness are regarded as much less important. In approaching this problem, the author takes essentially an cpigenetic view of cancer, arguing for the equivalence of the malignant state with that of a differentiated state: whatever enables cells to acquire heritable changes during development is essentially the same as the development of malignancy.

The books starts by lucidly reviewing the basic biological concepts that underlio approaches to the tumour problem, including a consideration of viruses, genetic influences and the essence of biochemical hypotheses. He gives very little attention to carcinogonic agents or $\mathrm{X}$-rays because, "while they are important for initiation of tumour they play no part in the continued abnormal growth of the tumour cells". He then goes on to consider tho regulation of cell division and the capacity of autonomous growth. This leads him to the nature of heritable cellular changes, and whether somatic mutation is an essential prerequisite. Ho concludes from consideration of viral transformation and the nature of differentiation that ". . . we have in the concept of active and inactive gene states within a constant cellular genome a very real and, above all, an experimentally testable alternative to the concept of somatic coll mutation as an explanation for the heritable cellular change that underlies the tumorous state gencrally". He also argues that there is evidence that the malignant state may be a potentially reversible event. This brief summary does not do justice to the large amount of information from a variety of systems, including plants that he so draws upon and describes.

In considering the normal and abnormal growth of cells, and in regarding the essential abnormality of tumour cells as their continued or autonomous growth, the author repeatedly expresses the view that, for a cell, the changes leading to cell division involve a radical reoricntation in biosynthetic metabolism. This is based on the idea that for cell division much of the cell's economy must be directed towards the synthesis of mitotic spindle proteins, which he suggests may comprise up to 30 per cent of the cell's total protein, and is almost certainly wrong. Current estimates of the amount of mierotubule protein in the spindle put it no higher than 0.2 per cent of the total protein. While this does not at all invalidate the main lines of argument in the book, it highlights its weakness: in attcmpting to interpret cancer within the framework of the control of cell division and differentiation of normal tissues, it is a bit like explaining the unknown in terms of the unknown. It is not, for cxample, just that our current ignorance of the control of ccll division is profound, but also at the concoptual level the discussion of the problem is still confused. We do not have a clear image of how we should think of the intracellular control of cell division which is the paradigm for coordination within the cell. Mitotic operons provide a useful shorthand for conccaling our ignorance when considering intercellular mechanisms, involving, for example, chalones, but cven here our ignorance is striking. The situation vis-à-vis differentiation is not much botter and the author is unfortunatcly too uncritical of the old concepts of embryonic organizers, fields and a plethora of inducing substance. I think I could make a strong case that organizer-inductor ideas were a conceptual error with near disastrous consequonces for developmental biology.

The great value of this book lies in bringing together critically, clearly and briefly, within the current framework of cell biology, some of tho essential features of the cancer problem. Its weakness is that the organizational problems of cell growth and development in terms of cell and mole. cular biology still elude us. But it gives hopes that this will not be for long.

LEWIS WOLPERT

\section{PERSONAL ENERGY}

\section{Energy and the Mitochondrion}

By David E. Green and Harold Baum. Pp. xii +205. (Academic Press: London and New York, January 1970.) $79 s$.

Ir is difficult to disparage a book by an eminent researcher, but in all humility I feel I must take an exception to this misleading tome.

If one wishes to know how Professor Green currently views the field of mitochondrial and membrane research and of oxidative phosphorylation, this is the book to read. This is substantiated by the fact that two thirds of all the "special articles" references are from his laboratory, and by the preface stating that "we have restricted our presentation to the point of view to which wo have been led by our experimental findings". The authors further stato 